\title{
Prevalence and Determinants of Antibiotic Consumption in the Elderly during 2006-2017
}

\author{
Silvia Portero de la Cruz ${ }^{1, *(1)}$ and Jesús Cebrino ${ }^{2}$ (D) \\ 1 Department of Nursing, Pharmacology and Physiotherapy, Faculty of Medicine and Nursing, \\ University of Córdoba, Avda. Menéndez Pidal, S/N, 14071 Córdoba, Spain \\ 2 Department of Preventive Medicine and Public Health, Faculty of Medicine, University of Seville, \\ Avda. Doctor Fedriani, S/N, 41009 Seville, Spain; jcebrino@us.es \\ * Correspondence: n92pocrs@uco.es; Tel.: +34-957-218-093
}

Received: 2 April 2020; Accepted: 5 May 2020; Published: 6 May 2020

\begin{abstract}
Elderly people are a particularly important population with regard to antibiotic overuse, using around 50\% more antibiotics per capita than younger adults. The aim of this study was to analyze the prevalence, associated factors and evolution over time of antibiotic consumption among the Spanish population aged $\geq 65$ years from 2006 to 2017. A descriptive cross-sectional study was conducted using data from the Spanish National Health Survey in 2006, 2011/2012 and 2017, and from the European Health Survey in Spain in 2009 and 2014. The sample consisted of 26,891 non-institutionalized individuals $\geq 65$ years. Antibiotic consumption was the dependent variable, and sociodemographic variables, lifestyle habits and health status were analyzed using a logistic regression model. The prevalence of antibiotic consumption was $4.94 \%$, with a marked increase from $2006(4.64 \%)$ to $2017(5.81 \%)(p<0.0001)$. Higher antibiotic consumption was associated with poor or very poor self-perceived health status, no polypharmacy and not having been in hospital during the previous twelve months, while a lower consumption was linked to being limited but not severely due to a health problem and not being at all limited.
\end{abstract}

Keywords: aged; anti-bacterial agents; public health; trends

\section{Introduction}

Antibiotics are essential drugs in the prevention or treatment of microbial infectious processes [1]. Nevertheless, the World Health Organization has reported that around $50 \%$ of antibiotic consumption is irrational, irresponsible or without any clinical need [2]. The elderly represents a particularly important population with respect to antibiotic overuse, using around $50 \%$ more antibiotics per capita than younger adults [3,4]. People aged $\geq 65$ years currently constitute $19.40 \%$ of the Spanish population [5], and the Spanish National Statistics Office predicts that this proportion will have increased to $25.20 \%$ by 2033 [6]. Age-related physiological changes place the elderly at high risk for infectious diseases due to a combination of factors, including immune senescence, altered skin and mucosal barrier function, degenerative changes in bone and cartilage, as well as a reduction in respiratory capacity [7-9]. In addition, infectious diseases are a leading cause of hospital admission and death in this patient population [10].

Inappropriate antibiotic therapy in older people entails significant risks and potentially adverse consequences, including the risk of drug interactions, side effects related to age or disease-related changes in metabolisms, as well as risks associated with multidrug-resistant organisms and Clostridium difficile infections $[9,11,12]$. In fact, one of the biggest public health problems worldwide is the emergence of resistance among bacterial pathogens [13]. 
Between 2000 and 2015, the consumption rate of antibiotics increased 39\% globally [14]. According to the European Surveillance of Antimicrobial Consumption Network, Spain is among the European countries with the highest rates, reaching 26 defined daily doses (DDD)/1000 inhabitants/day in 2018, which is higher than the mean 20.1 DDD/1000 inhabitants/day for the European Union during the same year [15].

In view of this situation, a number of studies have investigated the role of sociodemographic and clinical factors in the increasing antibiotic consumption around the world, so that prompt action aimed at encouraging appropriate antibiotic use can be taken [16-20]. Nevertheless, there are very few studies of antibiotic consumption in the Spanish population that focus on associated factors [21,22], especially among people aged $\geq 65$ years old [23]. The aim of this study was to analyze the prevalence, associated factors and evolution over time of antibiotic consumption among the Spanish population aged $\geq 65$ years from 2006 to 2017 .

\section{Materials and Methods}

A cross-sectional study was carried out from December 2019 to February 2020 using the data obtained from the records of the Spanish National Health Survey (SNHS) 2006 [24], the European Health Survey in Spain (EHSS) in 2009 [25], the SNHS 2011/2012 [26], the EHSS 2014 [27] and the SNHS 2017 [28]. The SNHS and EHSS are representative surveys of the general population (representativeness is ensured by assigning a weighting coefficient to each participant) carried out by the Ministry of Health, Consumer Affairs and Social Welfare in partnership with the National Institute of Statistics. These surveys are conducted in non-institutionalised Spanish residents through personalized interviews. The sampling design was multistage probabilistic, stratified by census areas (first stage), family homes (second stage) and individuals (third stage). The inclusion criteria, for the data analyzed in the present study, were people aged $\geq 65$ years old living in Spain.

The sample was representative of the older population residing in Spain and, originally, consisted of 33,306 subjects, but due to a lack of data for some of the variables studied, 6415 (19.26\%) were excluded when the descriptive, bivariate and multivariate statistical analyses were carried out. For the current study, the total sample of participants numbered 26,891: 5322 in 2006; 4125 in 2009; 5244 in 2011/2012; 5862 in 2014; and 6338 in 2017.

The dependent variable was "antibiotics consumption". This variable was assessed through the question "Have you taken antibiotics during the last two weeks?". Participants who answered "yes" were considered consumers of antibiotics. The independent variables were: year of the surveys (2006, 2011/2012, 2009, 2014, 2017), gender (male, female), age (65-74 years, 75-84 years, $\geq 85$ years), level of education (without studies, primary, secondary or professional training, university), marital status (single, married, widowed, separated/divorced), nationality (Spanish, foreigner), size of town of residence $(<10,000$ inhabitants, $10,000-100,000$ inhabitants, $>100,000$ inhabitants). The variables related to lifestyle and health status used in the study were self-perceived health (very good, good, fair, poor, very poor), currently smoking (yes, no), consumption of alcoholic beverages in the two weeks prior to the survey (yes, no), hospitalization during the past twelve months (yes, no), degree of limitation due to a health problem for at least six months (severely limited, limited but not severely, not at all limited) and polypharmacy (yes, no). Polypharmacy was calculated using an identical question in all the questionnaires: "From the following list of types of medication, please tell me which one(s) you have consumed in the last two weeks?". Subjects were classified as polypharmacy if they answered "yes" in five or more different medication groups (used to treat diseases such as colds, flu, throat or lung infections, symptoms such as pain or fever, or laxatives). Although no consensus has yet been reached on the number of medications that must be consumed to be considered polypharmacy, this figure (five medications) has been used in recent studies conducted in different countries [29-31]. The body mass index (BMI) was calculated from the self-reported body weight and height and categorized according to the World Health Organization [32] as: underweight (BMI $<18.50 \mathrm{~kg} / \mathrm{m}^{2}$ ), normal-weight (BMI ranged between 18.50- and $24.99 \mathrm{~kg} / \mathrm{m}^{2}$ ), overweight (BMI ranged between 25.00 and $29.99 \mathrm{~kg} / \mathrm{m}^{2}$ ), 
and obesity (BMI $\geq 30 \mathrm{~kg} / \mathrm{m}^{2}$ ). To identify subjects with an associated chronic condition, we used the self-reported affirmative answer to the presence of any of the following physician-diagnosed diseases (categorized as none, 1-2, $\geq 3$ ): arterial hypertension, hypercholesterolemia, asthma, chronic bronchitis, diabetes and cancer.

The data obtained from these surveys are available in the National Institute of Statistics and Ministry of Health, Consumer Affairs and Social Welfare websites [24-28] in the form of anonymized microdata: no special authorizations are therefore required for their use. According to the SNHS and EHSS methodologies, the microdata files are anonymous and are available to the public. In accordance with Spanish legislation, when secondary data are used, there is no need for approval from an Ethics Committee. Data research is available as Supplementary File.

A descriptive analysis was performed by calculating the counts and percentages for the qualitative variables. The proportions of categorical variables were compared using the chi-square test for contingency tables or Fisher's exact test if the number of expected frequencies was greater than 5 . In addition, a logistic regression was performed to identify the variables associated with antibiotic consumption. All variables with a significant association in the bivariate analysis were included in the multivariate analysis. Raw and adjusted odds ratios were calculated with $95 \%$ confidence intervals. The Wald statistic was used to exclude one by one from the model any variables with a $p \geq 0.15$ (backward methodical selection procedure). All the hypothesis contrasts were bilateral and in all the statistical tests, those with a 95\% confidence level $(p<0.05)$ were considered significant values. The statistical power for all analyses conducted was $80 \%$. The statistical analysis was carried out using IBM SPSS Statistics version 25 (IBM Corp, Armonk, NY, USA), licensed to the University of Córdoba and University of Seville.

\section{Results}

\subsection{Sociodemographic, Lifestyle and Health Status Variables}

Of the 42,157 subjects aged $\geq 65$ years who were invited to participate in the SNHS 2006, EHSS 2009, SNHS 2011/2012, EHSS 2014 and SNHS 2017, 8851 individuals were excluded due to the following reasons: 383 refused to participate, 268 were absent from their homes and 23 were unable to participate in SNHS 2006; 1213 refused to participate, 825 were absent from their homes and 83 were unable to participate in EHSS 2009; 1488 refused to participate, 931 were absent from their homes and 71 were unable to participate in SNHS 2011/2012; 154 refused to participate, 40 were absent from their homes and 28 were unable to participate in EHSS 2014; 1841 refused to participate, 1435 were absent from their homes and 68 were unable to participate in SNHS 2017.

Thus, the study was based on data from 33,306 individuals who accepted to participate. Of them, a total of 6415 (19.26\%) not answered, at least, one variable, so that they also were excluded. In that sense, in SNHS 2006, 2520 individuals were excluded who did not answer to the following variables: antibiotic consumption $(1.47 \%)$, level of education $(0.84 \%)$, BMI $(65.20 \%)$, marital status $(0.39 \%)$, nationality $(0.32 \%)$, polypharmacy $(30.01 \%)$, chronic condition $(1.05 \%)$ and consumption of alcoholic beverages (0.74\%). In EHSS 2009, 1900 individuals were excluded who did not answer to the antibiotic consumption $(0.31 \%)$, level of education $(0.53 \%)$, BMI $(40.43 \%)$, marital status $(0.22 \%)$, polypharmacy $(6.42 \%)$, chronic condition $(0.22 \%)$, currently smoking $(25.95 \%)$ and consumption of alcoholic beverages (25.92\%). In SNHS 2011/2012, 652 individuals were excluded who did not answer to the antibiotic consumption $(0.42 \%)$, BMI $(86.35 \%)$, marital status $(0.97 \%)$, polypharmacy $(8.64 \%)$, chronic condition $(0.70 \%)$, currently smoking $(1.25 \%)$, consumption of alcoholic beverages $(1.11 \%)$, hospitalization over the past twelve months $(0.28 \%)$ and degree of limitation due to a health problem (0.28\%). In EHSS 2014, 658 individuals were excluded who did not answer to the antibiotic consumption (1.17\%), BMI (71.43\%), marital status $(0.70 \%)$, polypharmacy $(21.66 \%)$, chronic condition $(1.29 \%)$, currently smoking $(1.64 \%)$, consumption of alcoholic beverages $(1.87 \%)$ and degree of limitation due to a health problem $(0.24 \%)$. In SNHS 2017, 685 individuals were excluded who did not answer to the antibiotic consumption 
$(0.26 \%)$, BMI $(83.72 \%)$, marital status $(1.42 \%)$, polypharmacy $(10.21 \%)$, chronic condition $(0.90 \%)$, currently smoking $(1.55 \%)$, consumption of alcoholic beverages $(1.81 \%)$ and degree of limitation due to a health problem $(0.13 \%)$.

Finally, the total sample was 26,891 records of older people, including $59 \%(n=15,865)$ women and $41 \%(n=11,026)$ men between 65 and 104 years old. The most frequent sociodemographic, lifestyle and health status characteristics of the participants were that they were married (51.90\%), lived in towns with a population of over 100,000 inhabitants (41.70\%), had no studies $(44.67 \%)$, were Spanish (97.55\%), had a fair self-perceived health status (35.03\%), had no polypharmacy $(78.53 \%)$, had, at least, one chronic condition $(71.73 \%)$, were overweight $(43.78 \%)$, were not current smokers $(88.23 \%)$, had not consumed alcohol in the last two weeks $(65.06 \%)$, had not been in hospital during the last twelve months $(86.25 \%)$ and did not report any limitation due to a health problems in the last six months $(57.50 \%)$.

Regarding the sociodemographic, lifestyle and health status variables of the sample according to the year of the survey (Table 1), a decrease in the number of older people without studies can be seen (2006: 82.71\%, 2017: 29.38\%; $p<0.0001$ ). There was also a decrease in the number of participants who were overweight (2006: 46.37\%, 2017: 44.38\%; $p<0.0001$ ).

\subsection{Antibiotic Consumption}

The overall prevalence of antibiotic consumption was $4.94 \%$. There were significant differences in antibiotic consumption between the different years of the study, with $4.64 \%$ consumption in 2006, compared to $5.81 \%$ in $2017(p<0.0001)$ (Figure 1$)$.

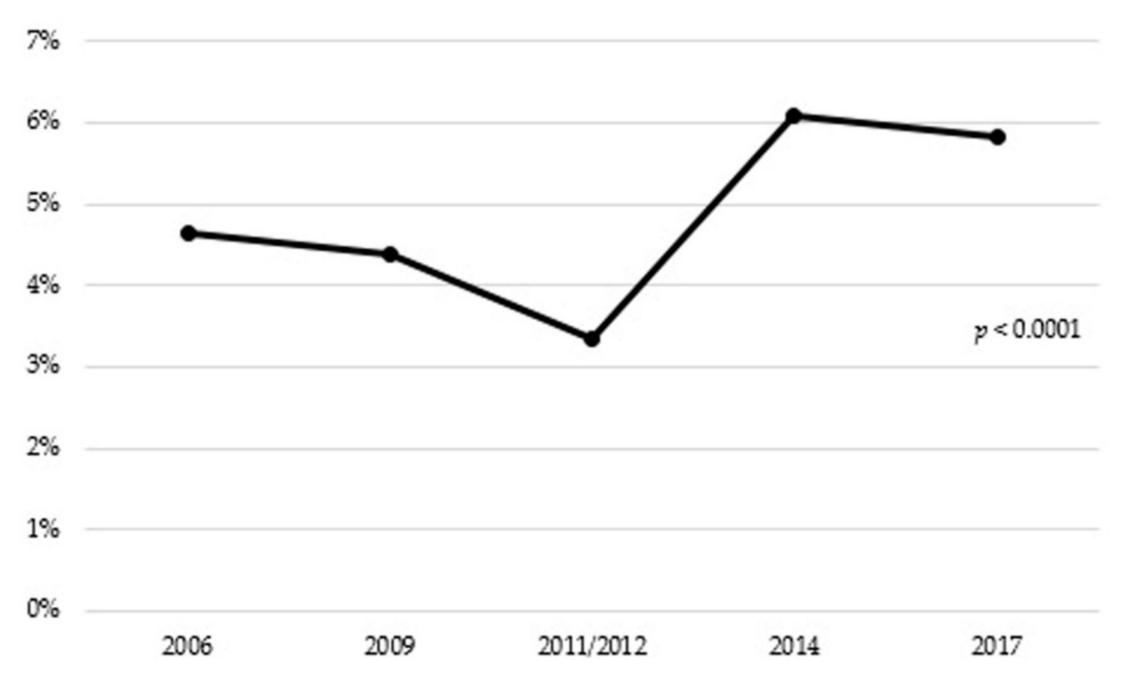

Figure 1. Antibiotic consumption in people aged 65 years or older in Spain (2006-2017).

\subsection{Association between Sociodemographic, Lifestyle, Health Status Variables and Antibiotic Consumption.}

The antibiotic consumption is distributed differently according to the sociodemographic, lifestyle and health status variables (Table 2). The bivariate analysis reveals a higher prevalence of antibiotic consumption in older people who reported not having polypharmacy $(50.38 \%, p<0.01)$ and currently being a non-smoker $(90.81 \%, p<0.01)$. A lower prevalence of antibiotic consumption was found in participants who had a very good self-perceived health status $(3.69 \%, p<0.0001)$, had no chronic diseases $(16.42 \%, p<0.0001)$, were severely limited $(21.39 \%, p<0.01)$ or had been in hospital in the last twelve months $(29.74 \%, p<0.01)$. In the multivariate analysis, from the year of 2014 , the probability of antibiotic consumption in older people was higher than in 2006 and also in those had not been in hospital in the last twelve months. This probability was more than double in participants with no polypharmacy and a poor or very poor self-perceived health status. In contrast, a clear downward trend was observed in the probability of antibiotic consumption as the degree of limitation due to a health problem decreased. 
Table 1. Sociodemographic, lifestyle and health status variables of Spanish people aged $\geq 65$ years $(\mathrm{N}=26,891)(2006-2017)$.

\begin{tabular}{|c|c|c|c|c|c|c|}
\hline Variables & $\begin{array}{c}2006 \\
n=5322(\%)\end{array}$ & $\begin{aligned} & 2009 \\
n= & 4125(\%)\end{aligned}$ & $\begin{array}{c}2011 / 2012 \\
n=5244(\%)\end{array}$ & $\begin{array}{c}2014 \\
n=5862(\%)\end{array}$ & $\begin{aligned} & 2017 \\
n= & 6338(\%)\end{aligned}$ & $p$-Value \\
\hline \multicolumn{7}{|l|}{ Gender } \\
\hline Male & $2230(41.90)$ & 1655 (40.12) & 1971 (37.59) & $2469(42.12)$ & $2701(42.62)$ & $<0.0001$ \\
\hline Female & 3092 (58.10) & $2470(59.88)$ & $3273(62.41)$ & 3393 (57.88) & 3637 (57.38) & \\
\hline \multicolumn{7}{|l|}{ Age group (years) } \\
\hline $65-74$ & 2855 (53.65) & $2092(50.72)$ & $2433(46.40)$ & 2934 (50.05) & 3181 (50.19) & \\
\hline $75-84$ & $2048(38.48)$ & $1649(39.98)$ & $2070(39.47)$ & $2140(36.51)$ & $2268(35.78)$ & $<0.0001$ \\
\hline$\geq 85$ & $419(7.87)$ & $384(9.30)$ & $741(14.13)$ & $788(13.44)$ & $889(14.03)$ & \\
\hline \multicolumn{7}{|l|}{ Level of education } \\
\hline Without studies & 4402 (82.72) & $1768(42.86)$ & $2080(39.66)$ & $1900(32.41)$ & $1862(29.38)$ & \\
\hline Primary & $228(4.28)$ & $1505(36.48)$ & $1214(23.15)$ & $2542(43.36)$ & 2327 (36.72) & $<0.0001$ \\
\hline Secondary or PT & $546(10.26)$ & $584(14.16)$ & $1670(31.85)$ & $926(15.80)$ & 1546 (24.39) & \\
\hline University & $146(2.74)$ & $268(6.50)$ & $280(5.34)$ & $494(8.43)$ & $603(9.51)$ & \\
\hline \multicolumn{7}{|l|}{ Marital status } \\
\hline Single & $543(10.20)$ & $343(8.32)$ & $1570(29.94)$ & 497 (8.48) & 505 (7.97) & \\
\hline Married & $2802(52.65)$ & $2141(51.90)$ & $2688(51.26)$ & 3005 (51.26) & $3320(52.38)$ & $<0.0001$ \\
\hline Widowed & $1851(34.78)$ & $1526(36.99)$ & $608(11.59)$ & $2146(36.61)$ & $2218(35.00)$ & \\
\hline Separated/Divorced & $126(2.37)$ & $115(2.79)$ & $378(7.21)$ & $214(3.65)$ & $295(4.65)$ & \\
\hline \multicolumn{7}{|l|}{ Nationality } \\
\hline Spanish & 5265 (98.93) & 4074 (98.76) & $4858(92.64)$ & $5790(98.77)$ & $6244(98.52)$ & $<0.0001$ \\
\hline Foreigner & $57(1.07)$ & $51(1.24)$ & $386(7.36)$ & $72(1.23)$ & $94(1.48)$ & \\
\hline \multicolumn{7}{|l|}{ Size of town of residence } \\
\hline$<10,000$ inhab & $1712(32.17)$ & $1050(25.45)$ & $1522(29.02)$ & $1506(25.69)$ & $1640(25.88)$ & \\
\hline $10,000-100,000$ inhab & $1638(30.78)$ & $1183(28.68)$ & $1550(29.56)$ & $1831(31.24)$ & $2045(32.26)$ & $<0.0001$ \\
\hline$>100,000$ inhab & $1972(37.05)$ & $1892(45.87)$ & $2172(41.42)$ & $2525(43.07)$ & $2653(41.86)$ & \\
\hline \multicolumn{7}{|l|}{ Body Mass Index } \\
\hline Underweight & $56(1.05)$ & $32(0.78)$ & $109(2.08)$ & $67(1.14)$ & $71(1.12)$ & \\
\hline Normal weight & $1537(28.88)$ & $1173(28.44)$ & $2316(44.16)$ & $1816(30.98)$ & $1966(31.02)$ & $<0.0001$ \\
\hline Overweight & $2468(46.37)$ & $1903(46.13)$ & $1965(37.47)$ & $2624(44.76)$ & $2813(44.38)$ & \\
\hline Obesity & $1261(23.69)$ & $1017(24.65)$ & $854(16.29)$ & $1355(23.12)$ & $1488(23.48)$ & \\
\hline
\end{tabular}


Table 1. Cont.

\begin{tabular}{|c|c|c|c|c|c|c|}
\hline Variables & $\begin{aligned} & 2006 \\
n= & 5322(\%)\end{aligned}$ & $\begin{array}{c}2009 \\
n=4125(\%)\end{array}$ & $\begin{array}{c}2011 / 2012 \\
n=5244(\%)\end{array}$ & $\begin{array}{c}2014 \\
n=5862(\%)\end{array}$ & $\begin{aligned} & 2017 \\
n= & 6338(\%)\end{aligned}$ & $p$-Value \\
\hline \multicolumn{7}{|l|}{ Self-perceived health } \\
\hline Very good & $322(6.05)$ & $204(4.95)$ & $1140(21.74)$ & $389(6.64)$ & $399(6.30)$ & \multirow{5}{*}{$<0.0001$} \\
\hline Good & $1823(34.25)$ & $1501(36.39)$ & $2547(48.57)$ & $2231(38.06)$ & $2516(39.70)$ & \\
\hline Fair & $2207(41.47)$ & $1653(40.07)$ & $1075(20.50)$ & $2129(36.32)$ & $2356(37.17)$ & \\
\hline Poor & $750(14.10)$ & $597(14.47)$ & $403(7.68)$ & $828(14.12)$ & $836(13.19)$ & \\
\hline Very poor & $220(4.13)$ & $170(4.12)$ & $79(1.51)$ & $285(4.86)$ & $231(3.64)$ & \\
\hline \multicolumn{7}{|l|}{ Polypharmacy } \\
\hline Yes & 1048 (19.69) & $1061(25.72)$ & $457(8.71)$ & $1515(25.84)$ & $1692(26.70)$ & \multirow[t]{2}{*}{$<0.0001$} \\
\hline No & $4274(80.31)$ & $3064(74.28)$ & $4787(91.29)$ & $4347(74.16)$ & $4646(73.30)$ & \\
\hline \multicolumn{7}{|l|}{ Number of chronic diseases } \\
\hline None & $1430(26.87)$ & $833(20.19)$ & $2774(52.90)$ & $1289(21.99)$ & $1274(20.10)$ & \multirow{3}{*}{$<0.0001$} \\
\hline $1-2$ & 3295 (61.91) & $2644(64.10)$ & $2112(40.27)$ & $3649(62.25)$ & $3768(59.45)$ & \\
\hline$\geq 3$ & $597(11.22)$ & $648(15.71)$ & $358(6.83)$ & $924(15.76)$ & $1296(20.45)$ & \\
\hline \multicolumn{7}{|l|}{ Currently smoking } \\
\hline Yes & $455(8.55)$ & $322(7.81)$ & $1349(25.72)$ & $472(8.05)$ & $567(8.95)$ & \multirow[t]{2}{*}{$<0.0001$} \\
\hline No & $4867(91.45)$ & $3803(92.19)$ & $3895(74.28)$ & $5390(91.95)$ & $5771(91.05)$ & \\
\hline \multicolumn{7}{|l|}{ Alcohol consumption } \\
\hline Yes & $508(9.55)$ & $1774(43.01)$ & $846(16.13)$ & $3010(51.35)$ & $3259(51.42)$ & \multirow[t]{2}{*}{$<0.0001$} \\
\hline No & $4814(90.45)$ & $2351(56.99)$ & $4398(83.87)$ & $2852(48.65)$ & $3079(48.58)$ & \\
\hline \multicolumn{7}{|c|}{ Hospitalization during the past twelve months } \\
\hline Yes & $774(14.54)$ & $683(16.56)$ & $468(8.92)$ & $841(14.35)$ & $931(14.69)$ & \multirow[t]{2}{*}{$<0.0001$} \\
\hline No & $4548(85.46)$ & $3442(83.44)$ & $4776(91.08)$ & $5021(85.65)$ & $5407(85.31)$ & \\
\hline \multicolumn{7}{|c|}{ Degree of limitation due to a health problem for at least six months } \\
\hline Severely limited & $491(9.23)$ & $416(10.08)$ & $184(3.51)$ & $728(12.42)$ & $635(10.02)$ & \multirow[t]{3}{*}{$<0.0001$} \\
\hline Limited but not severely & $1696(31.86)$ & $1730(41.94)$ & $894(17.05)$ & $2222(37.91)$ & $2434(38.40)$ & \\
\hline Not at all limited & $3135(58.91)$ & $1979(47.98)$ & $4166(79.44)$ & $2912(49.67)$ & $3269(51.58)$ & \\
\hline
\end{tabular}

PT: Professional Training; Inhab: Inhabitants. 
Table 2. Association between antibiotic consumption and sociodemographic, lifestyle and health status variables in Spanish people aged $\geq 65$ years $(n=26,891)$ (2006-2017).

\begin{tabular}{|c|c|c|c|c|c|}
\hline \multirow{2}{*}{ Variables } & \multicolumn{5}{|c|}{$\begin{array}{c}\text { Antibiotic Consumption } \\
\qquad n=1328\end{array}$} \\
\hline & $n(\%)$ & OR (CI 95\%) & $p$-Value & ORa (CI 95\%) & $p$-Value \\
\hline \multicolumn{6}{|l|}{ Year of the surveys } \\
\hline 2006 & $247(18.60)$ & Reference & & Reference & \\
\hline 2009 & $181(13.63)$ & $0.94(0.77-1.15)$ & 0.56 & $0.85(0.69-1.04)$ & 0.1 \\
\hline $2011 / 2012$ & $175(13.18)$ & $0.71(0.58-1.86)$ & 0.32 & $1.03(0.84-1.27)$ & 0.75 \\
\hline 2014 & $357(26.88)$ & $1.33(1.13-1.57)$ & $<0.001$ & $1.21(1.02-1.44)$ & 0.02 \\
\hline 2017 & $368(27.71)$ & $1.27(0.67-1.49)$ & 0.08 & $1.17(0.99-1.38)$ & 0.07 \\
\hline \multicolumn{6}{|l|}{ Gender } \\
\hline Male & $511(38.48)$ & Reference & 0.06 & & \\
\hline Female & $817(61.52)$ & $1.12(0.99-1.25)$ & & & \\
\hline \multicolumn{6}{|l|}{ Age group (years) } \\
\hline 65-74 & $663(49.92)$ & Reference & & & \\
\hline $75-84$ & $502(37.81)$ & $1.00(0.89-1.31)$ & 0.94 & & \\
\hline$\geq 85$ & $163(12.27)$ & $1.03(0.87-1.23)$ & 0.73 & & \\
\hline \multicolumn{6}{|l|}{ Level of education } \\
\hline Without studies & $613(46.16)$ & Reference & & & \\
\hline Primary & 365 (27.49) & $1.21(0.28-5.21)$ & 0.8 & & \\
\hline Secondary or PT & $257(19.35)$ & $1.76(0.14-4.02)$ & 0.75 & & \\
\hline University & $93(7.00)$ & $3.43(0.53-2.32)$ & 0.2 & & \\
\hline \multicolumn{6}{|l|}{ Marital status } \\
\hline Single & $124(9.34)$ & Reference & & & \\
\hline Married & $713(53.69)$ & $0.91(0.79-1.04)$ & 0.17 & & \\
\hline Widowed & $436(32.83)$ & $0.95(0.82-1.11)$ & 0.53 & & \\
\hline Separated/Divorced & $55(4.14)$ & $1.02(0.81-1.27)$ & 0.87 & & \\
\hline \multicolumn{6}{|l|}{ Nationality } \\
\hline Spanish & $1302(98.04)$ & Reference & 0.23 & & \\
\hline Foreigner & $26(1.96)$ & $1.27(0.86-1.89)$ & & & \\
\hline
\end{tabular}


Table 2. Cont.

\begin{tabular}{|c|c|c|c|c|c|}
\hline \multirow[t]{2}{*}{ Variables } & \multicolumn{5}{|c|}{$\begin{array}{l}\text { Antibiotic Consumption } \\
\qquad n=1328\end{array}$} \\
\hline & $n(\%)$ & OR (CI 95\%) & $p$-Value & ORa (CI 95\%) & $p$-Value \\
\hline \multicolumn{6}{|l|}{ Size of town of residence } \\
\hline$<10,000$ inhab & $334(25.15)$ & Reference & & & \\
\hline $10,000-100,000$ inhab & $431(32.46)$ & $1.17(0.81-1.36)$ & 0.08 & & \\
\hline$>100,000$ inhab & $563(42.39)$ & $1.12(0.98-1.29)$ & 0.1 & & \\
\hline \multicolumn{6}{|l|}{ Body Mass Index } \\
\hline Underweight & $15(1.13)$ & Reference & & & \\
\hline Normal weight & $409(30.80)$ & $1.04(0.61-1.76)$ & 0.89 & & \\
\hline Overweight & $551(41.49)$ & $1.05(0.62-1.77)$ & 0.86 & & \\
\hline Obesity & $353(26.58)$ & $1.34(0.79-2.27)$ & 0.28 & & \\
\hline \multicolumn{6}{|l|}{ Self-perceived health } \\
\hline Very good & $49(3.69)$ & Reference & & Reference & \\
\hline Good & $296(22.29)$ & $1.41(1.04-1.91)$ & 0.03 & $1.25(0.92-1.71)$ & 0.15 \\
\hline Fair & $506(38.10)$ & $2.79(2.07-3.75)$ & $<0.01$ & $1.63(1.19-2.23)$ & $<0.01$ \\
\hline Poor & $360(27.11)$ & $5.79(4.27-7.84)$ & $<0.01$ & $2.34(1.67-3.27)$ & $<0.01$ \\
\hline Very poor & $117(8.81)$ & $6.61(4.67-9.32)$ & $<0.01$ & $2.14(1.46-3.14)$ & $<0.01$ \\
\hline \multicolumn{6}{|l|}{ Polypharmacy } \\
\hline Yes & $659(49.62)$ & Reference & $<0.01$ & Reference & $<0.01$ \\
\hline No & $669(50.38)$ & $3.94(3.52-4.41)$ & & $2.57(2.26-2.92)$ & \\
\hline \multicolumn{6}{|l|}{ Number of chronic diseases } \\
\hline None & $218(16.42)$ & Reference & & & \\
\hline $1-2$ & $775(58.36)$ & $1.79(1.53-2.08)$ & $<0.01$ & & \\
\hline$\geq 3$ & $335(25.22)$ & $3.25(2.73-3.88)$ & $<0.01$ & & \\
\hline \multicolumn{6}{|l|}{ Currently smoking } \\
\hline Yes & $122(9.19)$ & Reference & $<0.01$ & & \\
\hline No & $1206(90.81)$ & $0.75(0.62-0.91)$ & & & \\
\hline \multicolumn{6}{|l|}{ Alcohol consumption } \\
\hline Yes & $432(32.53)$ & Reference & 0.06 & & \\
\hline No & $896(67.47)$ & $0.89(0.79-1)$ & & & \\
\hline
\end{tabular}


Table 2. Cont

\begin{tabular}{|c|c|c|c|c|c|}
\hline \multirow{2}{*}{ Variables } & \multicolumn{5}{|c|}{$\begin{array}{l}\text { Antibiotic Consumption } \\
\qquad n=1328\end{array}$} \\
\hline & $n(\%)$ & OR (CI 95\%) & $p$-Value & ORa (CI 95\%) & $p$-Value \\
\hline \multicolumn{6}{|c|}{ Hospitalization during the past twelve months } \\
\hline Yes & $395(29.74)$ & Reference & $<0.01$ & Reference & $<0.01$ \\
\hline No & $933(70.26)$ & $2.85(2.52-3.23)$ & & $1.89(1.67-2.16)$ & \\
\hline \multicolumn{6}{|c|}{ Degree of limitation due to a health problem for at least six months } \\
\hline Severely limited & $284(21.39)$ & Reference & & Reference & \\
\hline Limited but not severely & $586(44.12)$ & $0.53(0.46-0.62)$ & $<0.01$ & $0.81(0.69-0.96)$ & $<0.01$ \\
\hline Not at all limited & $458(34.49)$ & $0.23(0.20-0.27)$ & $<0.01$ & $0.67(0.55-0.82)$ & $<0.01$ \\
\hline
\end{tabular}

PT: Professional Training; Inhab: Inhabitants; OR: odds ratio; ORa: odds ratio adjusted for all sociodemographic, lifestyle and health status variables; CI 95\%: $95 \%$ Confidence Interval; $\mathrm{n}$ : number of people consuming antibiotics. Nagelkerke's R Square $=0.09$. 


\section{Discussion}

The overall prevalence of antibiotic consumption in older people from 2006 to 2017 in Spain was $4.94 \%$. This percentage was lower compared to previous studies conducted among the non-institutionalized elderly population, which ranged from $11 \%$ to $45 \%$, with a significant rise over the past decade [23,33-36]. The variation observed may be due to multiple factors, rather than differences in health-care systems, including the number of general practitioners in a country, antibiotic dose regimens, guidelines, patients' expectations and the attitude towards taking medication, cultural and social factors, as well as the source of information available to the general practitioners [37].

The trend of increases in antibiotic use from 2006 to 2017 among older adults shown in our study supports previous reports $[23,38]$. One factor that should be taken into account is the influence of seasonal fluctuation in the antibiotic consumption. A number of studies $[39,40]$ have reported a remarkable seasonal variation in the antibiotic consumption in Spain with a winter predominance over summer, reflecting an inappropriate prescribing of antibiotic for respiratory tract infections caused by viruses. Nevertheless, in this study it was not possible to evaluate the seasonal fluctuation. The significant decrease in antibiotic use observed from 2009 (4.39\%) to 2011/2012 (3.34\%) may be due to the economic crisis that affected Spain from 2008 to 2013 [41], which led to the reduction of the purchasing power of elderly persons and the prescriptions were more closely controlled. Some authors have noted a decrease in the antibiotic consumption during that period [42]. After the economic crisis, in Spain, in 2014, there was an increase in the percentage of urinary and respiratory tract infections with respect to the period from 2009 to 2013 (16.7\% and $11.1 \%$ increase, respectively) [43], which could explain the significant spike in antibiotic consumption observed in 2014. Likewise, in 2016, there was also an increase in the percentage of urinary and respiratory tract infections with respect to the period from 2011 to 2015 ( $22 \%$ and 5.5\% increase, respectively) [44]. Although an increase in the percentage of infections is reported over the years, the antibiotic consumption decreased from 2014 to 2017. This situation may be explained because, in 2014, the Spanish Agency for Medication and Healthcare Pro-ducts promoted the creation of the National Programme against Antibiotic Resistance (PRAN) [45], in response to the European Commission request to address the problem following a common strategy [46]. In contrast, a constant rising trend of overall antibiotic use can be observed in national populations of older adults from Canada [47] and United States [48-50] and a decreasing trend in Denmark [51]. Whether this reflects changes in prescribing practices in this age group or differences in data sources is unclear.

Although women are about $27 \%$ more likely than men to receive antibiotic prescriptions due to the greater frequency of symptomatic infections of the urinary tract in women than in men, genetic and the over-use of primary healthcare services by women [52], this was not evident in the present study. Moreover, no relationship was found between antibiotic consumption and the participant's age. While most studies point out that older people are more likely than younger adults to report having taken antibiotics $[23,36,52]$, this increase can be explained by physiological changes in specific immune response patterns [52]. On the other hand, educational level was not associated with antibiotic consumption. In that sense, it has been reported the different role of education in developing countries, where it may improve access to medical treatment, than in developed countries, where access to medical treatment may not depend on educational levels [53,54]. Furthermore, in line with other studies [20,55], no relationship was found between antibiotic consumption and marital status. Regarding nationality, we found no significant differences between antibiotic consumption in Spanish and foreign elderly people. Cultural factors such as power distance, uncertainty avoidance and masculinity versus femininity are often referred to as possible explanations of differences in antibiotic consumption between people of different nationalities [56,57]. In addition, while the size of the town in which the participants lived was not associated with antibiotic consumption, city dwellers tend to report a higher use of antibiotics, which could be the result of having easier access to medical care, such as the greater availability of health care providers [58]. 
Despite the fact that we did not find any relationship between the BMI and antibiotic consumption, people who are overweight or obese are more likely to acquire an infection and thus need antibiotics compared with normal weight adults [59,60]. As found in another study [61], the likelihood of antibiotic consumption was greater in older people having a worse self-perceived health status, which may be because in a health system like the Spanish one, where access to care is universal, people with worse perceived health status visit their doctor regardless of their age. In the present study, the probability of antibiotic consumption was more than double in older people who had no polypharmacy. The concomitant use of multiple drugs can mask symptoms of infection, thus hampering diagnosis and necessitating prescription of broad-spectrum antimicrobial drugs to provide full antibiotic coverage [12,62]. As found by Palacios et al. [23], chronic diseases were significantly associated with the consumption of antibiotics. Patients with comorbidity and multimorbidity have increased susceptibility to infection due to poor mobility and/or perceptions around these patients' risk of infection-related complications [63]. Regarding tobacco consumption, we found that antibiotic use was lower in non-smokers than in current smokers; similar results were found in another study [59]. Cigarette smoking compromises the immune system, leading to higher rates of respiratory and other infections $[64,65]$. Moreover, despite the fact that alcohol impacts both the innate and the acquired immune system and, thus, increases the risk of infectious diseases [66,67], in our study, no relationship was found between alcohol consumption and antibiotic use.

Although hospitalization has been reported as a risk factor for antibiotic consumption [62], in our study, the probability of antibiotic consumption was higher in older people who had not been in hospital in the past twelve months. In fact, the vast majority of human consumption of antibiotics occurs in the community [15]. This may reflect the fact that patients need and demand quick relief from their symptoms, which seems to favor the prescription of antibiotics because doctors, especially those in the community, tend to respond to patients' needs by prescribing antibiotics $[68,69]$. On the other hand, the probability of antibiotic consumption decreased as the degree of limitation was reduced. The results from a number of studies have suggested that a higher degree of limitation is related with increased risk of infection [12] and antibiotic resistance [70] in elderly persons. Furthermore, limitation due to a health problem is a predictor of mortality and a criterion for the early use of antibiotics in this population [12].

The results of this study should be taken into consideration by health authorities when designing (or improving current) guidelines and strategies for promoting the correct use of antibiotics, especially considering the elderly population. Improving antimicrobial stewardship is an international priority due to the evolving threat of antibiotic resistance. Continuous reassessments of the medication regime and current clinical status of older people by physicians and nurses are required to avoid the increase of antibiotic consumption and resistance.

The present study also has some limitations. First, due to the cross-sectional design, it is not possible to assign causality between the variables. Second, it should be remembered that the data collected in the survey was obtained indirectly from the informants' self-reporting, which can be affected by memory and/or social desirability bias. Third, individuals can overestimate or underestimate their antibiotic consumption due to the self-reported measure of antibiotic consumption. Fourth, it was not possible to take into account the influence of seasonal factors in the antibiotic consumption and elderly people in institutions or hospitals have not been included. Fifth, since neither the SNHS not the EHSS identified specific active pharmaceutical ingredients (only groups of medicines for specific diseases or disorders) or the adequacy of antibiotic prescription, it would be advisable to include specific active pharmaceutical ingredients and a correct assessment of antibiotic prescription in future studies. Sixth, the amount of the total variance explained by the logistic regression model was modest, suggesting the importance of additional variables not explored by the different surveys. Seventh, BMI was calculated from height and weight reported by the participants, which may not be accurate. Lastly, although participation rate was relatively high, a non-participation bias cannot be ruled out, as it was not possible to compare the characteristics of the patients included in the study and those 
of who did not consent to participate. One strength of our study is that since the data were derived from a national survey, they have been obtained using carefully planned methodology, including sampling, well-designed forms, preparation of the survey participants, and supervision of the survey and filtering of the data, all of which guarantee a representative sample of the population.

\section{Conclusions}

In conclusion, the prevalence of antibiotic consumption in the Spanish population aged $\geq 65$ years increased significantly from 2006 to 2017 and is still within the normal range of consumption. Nonetheless, it could potentially become a serious public health concern if the trend of antibiotic consumption continues to increase over time. The probability of antibiotic consumption is higher in older people with poor or very poor self-perceived health status, no polypharmacy and who had not been in hospital in the last twelve months, and is lower as the degree of limitation due to a health problem decreases.

Supplementary Materials: The following are available online at http:/www.mdpi.com/1660-4601/17/9/3243/s1, File S1: Research data.

Author Contributions: Conceptualization, S.P.d.1.C. and J.C.; methodology, S.P.d.l.C. and J.C.; software, S.P.d.1.C. and J.C.; validation, S.P.d.1.C. and J.C.; formal analysis, S.P.d.l.C.; investigation, S.P.d.l.C. and J.C.; resources, S.P.d.l.C. and J.C.; data curation, S.P.d.l.C. and J.C.; writing-original draft preparation, S.P.d.l.C. and J.C.; writing-review and editing, S.P.d.I.C. and J.C.; visualization, S.P.d.l.C. and J.C.; supervision, J.C.; project administration, S.P.d.l.C. and J.C. All authors have read and agreed to the published version of the manuscript.

Funding: This research received no specific grant from any funding agency.

Conflicts of Interest: The authors declare no conflict of interest.

\section{References}

1. Coates, A.R.M.; Hu, Y.; Holt, J.; Yeh, P. Antibiotic combination therapy against resistant bacterial infections: Synergy, rejuvenation and resistance reduction. Expert Rev. Anti-Infect. Ther. 2020, 18, 5-15. [CrossRef] [PubMed]

2. World Health Organization (WHO). WHO Report on Surveillance of Antibiotic Consumption 2016-2018 Early Implementation. 2018. Available online: https://www.who.int/medicines/areas/rational_use/whoamramc-report-20181109.pdf (accessed on 26 February 2020).

3. Hicks, L.A.; Bartoces, M.G.; Roberts, R.M.; Suda, K.J.; Hunkler, R.J.; Taylor, T.H., Jr.; Schrag, S.J. US outpatient antibiotic prescribing variation according to geography, patient population, and provider specialty in 2011. Clin. Infect. Dis. 2015, 60, 1308-1316. [CrossRef] [PubMed]

4. Arizpe, A.; Reveles, K.R.; Aitken, S.L. Regional variation in antibiotic prescribing among medicare part D enrolees, 2013. BMC Infect. Dis. 2016, 16, 744. [CrossRef] [PubMed]

5. Instituto Nacional de Estadística (INE). Indicadores de Estructura de la Población. Proporción de Personas Mayores de Cierta Edad por Provincia. Available online: https://www.ine.es/jaxiT3/Tabla.htm?t=1488\&L=0 (accessed on 26 February 2020).

6. Instituto Nacional de Estadística (INE). Proyecciones de Población 2018. Available online: https://www.ine. es/prensa/pp_2018_2068.pdf (accessed on 26 February 2020).

7. El Chakhtoura, N.G.; Bonomo, R.A.; Jump, R.L.P. Influence of aging and environment on presentation of infection in older adults. Infect. Dis. Clin. N. Am. 2017, 31, 593-608. [CrossRef]

8. Esme, M.; Topeli, A.; Balam Yavuz, B.; Akova, M. Infections in the elderly critically-III patients. Front. Med. 2019, 6, 118. [CrossRef]

9. Beckett, C.L.; Harbarth, S.; Huttner, B. Special considerations of antibiotic prescription in the geriatric population. Clin. Microbiol. Infect. 2015, 21, 3-9. [CrossRef]

10. Ittisanyakorn, M.; Ruchichanantakul, S.; Vanichkulbodee, A.; Sri-On, J. Prevalence and factors associated with one-year mortality of infectious diseases among elderly emergency department patients in a middle-income country. BMC Infect. Dis. 2019, 19, 662. [CrossRef] 
11. Lessa, F.C.; Mu, Y.; Bamberg, W.M.; Beldavs, Z.G.; Dumyati, G.K.; Dunn, J.R.; Farley, M.M.; Holzbauer, S.M.; Meek, J.I.; Phipps, E.C.; et al. Burden of Clostridium difficile infection in the United States. N. Engl. J. Med. 2015, 372, 825-834. [CrossRef]

12. Corsonello, A.; Abbatecola, A.M.; Fusco, S.; Luciani, F.; Marino, A.; Catalano, S.; Maggio, M.G.; Lattanzio, F. The impact of drug interactions and polypharmacy on antimicrobial therapy in the elderly. Clin. Microbiol. Infect. 2015, 21, 20-26. [CrossRef]

13. Munita, J.M.; Arias, C.A. Mechanisms of antibiotic resistance. Microbiol. Spectr. 2016, 4. [CrossRef]

14. Klein, E.Y.; van Boeckel, T.P.; Martinez, E.M.; Pant, S.; Gandra, S.; Levin, S.A.; Goossens, H.; Laxminarayan, R. Global increase and geographic convergence in antibiotic consumption between 2000 and 2015. Proc. Natl. Acad. Sci. USA 2018, 115, E3463-E3470. [CrossRef] [PubMed]

15. European Centre for Disease Prevention and Control (ECDC). Antimicrobial Consumption in the EU/EEA. Annual Epidemiological Report for 2018. Available online: https:/www.ecdc.europa.eu/sites/default/files/ documents/Antimicrobial-consumption-EU-EEA.pdf (accessed on 26 February 2020).

16. Matuz, M.; Benko, R.; Doro, P.; Hajdu, E.; Nagy, G.; Nagy, E.; Nagy, E.; Monnet, D.L.; Soos, G. Regional variations in community consumption of antibiotics in Hungary, 1996-2003. Br. J. Clin. Pharmacol. 2005, 61, 96-100. [CrossRef] [PubMed]

17. Filippini, M.; Masiero, G.; Moschetti, K. Socioeconomic determinants of regional differences in outpatient antibiotic consumption: Evidence from Switzerland. Health Policy 2006, 78, 77-92. [CrossRef] [PubMed]

18. Masiero, G.; Filippini, M.; Ferech, M.; Goossens, H. Socioeconomic determinants of outpatient antibiotic use in Europe. Int. J. Public Health 2010, 55, 469-478. [CrossRef] [PubMed]

19. Bruyndonckx, R.; Hens, N.; Aerts, M.; Goossens, H.; Molenberghs, G.; Coenen, S. Measuring trends of outpatient antibiotic use in Europe: Jointly modelling longitudinal data in defined daily doses and packages. J. Antimicrob. Chemother. 2014, 69, 1981-1986. [CrossRef]

20. Ardoino, I.; Mannucci, P.M.; Nobili, A.; Franchi, C.; Tettamanti, M.; Pasina, L.; Corrao, S.; Marengoni, A.; Salerno, F.; Cesari, M.; et al. Antibiotic use and associated factors in a large sample of hospitalised older people. J. Glob. Antimicrob. Resist. 2019, 19, 167-172. [CrossRef]

21. Serna, M.C.; Real, J.; Ribes, E.; Marsal, J.R.; Godoy, P.; Galván, L. Determinantes de la prescripción de antibióticos en atención primaria. Enferm. Infecc. Microbiol. Clin. 2011, 29, 193-200. [CrossRef]

22. Malo Fumanal, S.; Rabanaque Hernández, M.J.; Feja Solana, C.; Lallana Álvarez, M.J.; Armesto Gómez, J.; Bjerrum, L. Differences in outpatient antibiotic use between a Spanish region and a Nordic country. Enferm. Infecc. Microbiol. Clin. 2014, 32, 412-417. [CrossRef]

23. Palacios Ceña, D.; Hernández Barrera, V.; Jiménez Trujillo, I.; Serrano Urrea, R.; Fernández de las Peñas, C.; Carrasco Garrido, P. Time trends in antibiotic consumption in the elderly: Ten-year follow-up of the Spanish National Health Survey and the European Health Interview Survey for Spain (2003-2014). PLoS ONE 2017, 12, e0185869. [CrossRef]

24. Ministerio de Sanidad Servicios Sociales e Igualdad, Instituto Nacional de Estadística. Encuesta Europea de Salud en España ENSE 2006; Ministerio de Sanidad, Servicios Sociales e Igualdad: Madrid, Spain, 2007. Available online: https://www.mscbs.gob.es/estadEstudios/estadisticas/encuestaNacional/encuesta2006.htm (accessed on 12 February 2020).

25. Ministerio de Sanidad Servicios Sociales e Igualdad, Instituto Nacional de Estadística. Encuesta Europea de Salud en España EESE 2009; Ministerio de Sanidad, Servicios Sociales e Igualdad: Madrid, Spain, 2010. Available online: https://www.mscbs.gob.es/estadEstudios/estadisticas/EncuestaEuropea/Enc_Eur_Salud_ en_Esp_2009.htm (accessed on 12 February 2020).

26. Ministerio de Sanidad Servicios Sociales e Igualdad, Instituto Nacional de Estadística. Encuesta Nacional de Salud España ENSE 2011/12; Ministerio de Sanidad, Servicios Sociales e Igualdad: Madrid, Spain, 2013. Available online: https://www.mscbs.gob.es/estadEstudios/estadisticas/encuestaNacional/encuesta2011.htm (accessed on 12 February 2020).

27. Ministerio de Sanidad Servicios Sociales e Igualdad, Instituto Nacional de Estadística. Encuesta Europea de Salud en España EESE 2014; Ministerio de Sanidad, Servicios Sociales e Igualdad: Madrid, Spain, 2015. Available online: https://www.mscbs.gob.es/estadEstudios/estadisticas/EncuestaEuropea/Enc_Eur_Salud_ en_Esp_2014.htm (accessed on 12 February 2020). 
28. Ministerio de Sanidad Servicios Sociales e Igualdad, Instituto Nacional de Estadística. Encuesta Nacional de Salud España ENSE 2017; Ministerio de Sanidad, Servicios Sociales e Igualdad: Madrid, Spain, 2018. Available online: https://www.mscbs.gob.es/estadEstudios/estadisticas/encuestaNacional/encuesta2017.htm (accessed on 12 February 2020).

29. Eiras, A.; Teixeira, M.A.; González Montalvo, J.I.; Castell, M.V.; Queipo, R.; Otero, Á. Consumption of drugs in over 65 in Porto (Portugal) and risk of potentially inappropriate medication prescribing. Aten. Primaria 2016, 48, 110-120. [CrossRef]

30. Lopes, L.M.; Figueiredo, T.P.; Costa, S.C.; Reis, A.M. Use of potentially inappropriate medications by the elderly at home. Cien. Saude. Colet. 2016, 21, 3429-3438. [CrossRef] [PubMed]

31. Urfer, M.; Elzi, L.; Dell-Kuster, S.; Bassetti, S. Intervention to improve appropriate prescribing and reduce polypharmacy in elderly patients admitted to an Internal Medicine Unit. PLoS ONE 2016, 11, e0166359. [CrossRef] [PubMed]

32. World Health Organization (WHO). Body Mass Index (BMI). Available online: http://www.euro.who. int/en/health-topics/disease-prevention/nutrition/a-healthy-lifestyle/body-mass-index-bmi (accessed on 26 March 2020).

33. Kong, L.S.; Islahudin, F.; Muthupalaniappen, L.; Chong, W.W. Knowledge and expectations on antibiotic use among older adults in Malaysia: A cross-sectional survey. Geriatrics 2019, 4, 61. [CrossRef] [PubMed]

34. Williamson, D.A.; Roos, R.; Verrall, A.; Smith, A.; Thomas, M.G. Trends, demographics and disparities in outpatient antibiotic consumption in New Zealand: A national study. J. Antimicrob. Chemother. 2016, 71, 3593-3598. [CrossRef]

35. Fleming-Dutra, K.E.; Hersh, A.L.; Shapiro, D.J.; Bartoces, M.; Enns, E.A.; File, T.M., Jr.; Finkelstein, J.A.; Gerber, J.S.; Hyun, D.Y.; Linder, J.A.; et al. Prevalence of inappropriate antibiotic prescriptions among US ambulatory care visits, 2010-2011. JAMA 2016, 315, 1864-1873. [CrossRef]

36. World Health Organization (WHO). Antibiotic Resistance: Multi-Country Public Awareness Survey 2015. Available online: https://apps.who.int/iris/bitstream/handle/10665/194460/9789241509817_eng.pdf; jsessionid=3190033119FDBF2535D991906A2817D0? sequence=1 (accessed on 1 March 2020).

37. Mor, A.; Frøslev, T.; Thomsen, R.W.; Oteri, A.; Rijnbeek, P.; Schink, T.; Garbe, E.; Pecchioli, S.; Innocenti, F.; Bezemer, I.; et al. Antibiotic use varies substantially among adults: A cross-national study from five European countries in the ARITMO project. Infection 2015, 43, 453-472. [CrossRef]

38. Kim, Y.A.; Park, Y.S.; Youk, T.; Lee, H.; Lee, K. Changes in antimicrobial usage patterns in Korea: 12-year analysis based on database of the National Health Insurance Service-national sample cohort. Sci. Rep. 2018, 8, 12210. [CrossRef]

39. Malo, S.; Bjerrum, L.; Feja, C.; Lallana, M.J.; Moliner, J.; Rabanaque, M.J. Compliance with recommendations on outpatient antibiotic prescribing for respiratory tract infections: The case of Spain. Basic Clin. Pharmacol. Toxicol. 2015, 116, 337-342. [CrossRef]

40. Lázaro Bengoa, E.; de Abajo Iglesias, F.J.; López Navas, A.; Fernández Cortizo, M.J. Uso de antibióticos en España y marco regulador para su desarrollo clínico en la Unión Europea. Enferm. Infecc. Microbiol. Clin. 2010, 28, 10-16. [CrossRef]

41. López Valcárcel, B.G.; Barber, P. Economic crisis, austerity policies, health and fairness: Lessons learned in Spain. Appl. Health Econ. Health Policy 2017, 15, 13-21. [CrossRef]

42. Rojas García, P.; Antoñanzas Villar, F. Effects of economic and health policies on the consumption of antibiotics in a Spanish region. Expert. Rev. Pharmacoecon. Outcomes Res. 2019, 1-8. [CrossRef] [PubMed]

43. Red Nacional de Vigilancia Epidemiológica-Instituto de Salud Carlos III, Ministerio de Economía y Competitividad y Ministerio de Sanidad, Servicios Sociales e Igualdad de España. Resultados de la Vigilancia Epidemiológica de las Enfermedades Transmisibles: Informe Anual (Año 2014). Available online: http://gesdoc.isciii.es/gesdoccontroller?action=download\&id=14/10/2016-3a996e69f2 (accessed on 1 May 2020).

44. Red Nacional de Vigilancia Epidemiológica-Instituto de Salud Carlos III y Ministerio Ciencia, Innovación y Universidades de España. Resultados de la Vigilancia Epidemiológica de las Enfermedades Transmisibles: Informe Anual (Año 2016). Available online: http://gesdoc.isciii.es/gesdoccontroller?action=download\&id= 25/01/2019-d8ee271b6f (accessed on 1 May 2020). 
45. Plan Nacional frente a la Resistencia a los Antibióticos (PRAN). Plan Estratégico y de Acción para Reducir el Riesgo de Selección y Diseminación de la Resistencia a los Antibióticos (2014). Available online: http://resistenciaantibioticos.es/es/system/files/content_images/plan_nacional_resistencia_ antibioticos.pdf (accessed on 1 May 2020).

46. Comisión Europea. Comunicación de la Comisión al Parlamento Europeo y al Consejo: Plan de Acción Contra la Amenaza Creciente de las Resistencias Bacterianas. 2011. Available online: https://ec.europa.eu/ transparency/regdoc/rep/1/2011/ES/1-2011-748-ES-F1-1.Pdf (accessed on 1 May 2020).

47. Tan, C.; Graves, E.; Lu, H.; Chen, A.; Li, S.; Schwartz, K.L.; Daneman, N. A decade of outpatient antimicrobial use in older adults in Ontario: A descriptive study. CMAJ Open 2017, 5, E878-E885. [CrossRef] [PubMed]

48. Olesen, S.W.; Barnett, M.L.; MacFadden, D.R.; Lipsitch, M.; Grad, Y.H. Trends in outpatient antibiotic use and prescribing practice among US older adults, 2011-15: Observational study. BMJ 2018, 362, k3155. [CrossRef]

49. Kabbani, S.; Palms, D.; Bartoces, M.; Stone, N.; Hicks, L.A. Outpatient antibiotic prescribing for older adults in the United States: 2011 to 2014. J. Am. Geriatr. Soc. 2018, 66, 1998-2002. [CrossRef] [PubMed]

50. Mundkur, M.L.; Franklin, J.; Huybrechts, K.F.; Fischer, M.A.; Kesselheim, A.S.; Linder, J.A.; Landon, J.; Patorno, E. Changes in outpatient use of antibiotics by adults in the United States, 2006-2015. Drug Saf. 2018, 41, 1333-1342. [CrossRef] [PubMed]

51. Kristensen, P.K.; Johnsen, S.P.; Thomsen, R.W. Decreasing trends, and geographical variation in outpatient antibiotic use: A population-based study in Central Denmark. BMC Infect. Dis. 2019, 19, 337. [CrossRef]

52. Schröder, W.; Sommer, H.; Gladstone, B.P.; Foschi, F.; Hellman, J.; Evengard, B.; Tacconelli, E. Gender differences in antibiotic prescribing in the community: A systematic review and meta-analysis. J. Antimicrob. Chemother. 2016, 71, 1800-1806. [CrossRef]

53. Ocan, M.; Obuku, E.A.; Bwanga, F.; Akena, D.; Richard, S.; Ogwal-Okeng, J.; Obua, C. Household antimicrobial self-medication: A systematic review and meta-analysis of the burden, risk factors and outcomes in developing countries. BMC Public Health 2015, 15, 742. [CrossRef]

54. Kliemann, B.S.; Levin, A.S.; Moura, M.L.; Boszczowski, I.; Lewis, J.J. Socioeconomic determinants of antibiotic consumption in the state of São Paulo, Brazil: The effect of restricting over-the-counter sales. PLoS ONE 2016, 11, e0167885. [CrossRef]

55. Al Rasheed, A.; Yagoub, U.; Alkhashan, H.; Abdelhay, O.; Alawwad, A.; Al Aboud, A.; Al Battal, S. Prevalence and predictors of self-medication with antibiotics in Al Wazarat Health Center, Riyadh City, KSA. Biomed Res. Int. 2016, 2016, 3916874. [CrossRef]

56. Hofstede, G. Dimensions of national cultures. In Diversity and Unity in Cross-Cultural Psychology; Rath, R., Asthana, H.S., Sinha, D., Sinha, J.B.H., Eds.; Swets and Zeitlinger: Lisse, The Netherlands, 1982.

57. Touboul-Lundgren, P.; Jensen, S.; Drai, J.; Lindbæk, M. Identification of cultural determinants of antibiotic use cited in primary care in Europe: A mixed research synthesis study of integrated design "Culture is all around us". BMC Public Health 2015, 15, 908. [CrossRef] [PubMed]

58. Russo, V.; Monetti, V.M.; Guerriero, F.; Trama, U.; Guida, A.; Menditto, E.; Orlando, V. Prevalence of antibiotic prescription in southern Italian outpatients: Real-world data analysis of socioeconomic and sociodemographic variables at a municipality level. ClinicoEcon. Outcomes Res. 2018, 10, 251-258. [CrossRef] [PubMed]

59. Mor, A.; Baggesen, L.M.; Søgaard, M.; Pedersen, L.; Larsen, F.B.; Sørensen, H.T.; Thomsen, R.W. The association of lifestyle with antibiotic consumption. Epidemiology 2015, 26, e58-e59. [CrossRef] [PubMed]

60. Furlong, M.; Deming-Halverson, S.; Sandler, D.P. Chronic antibiotic use during adulthood and weight change in the Sister Study. PLoS ONE 2019, 14, e0216959. [CrossRef]

61. Schuts, E.C.; van Dulm, E.; Boyd, A.; Snijder, M.B.; Geerlings, S.E.; Prins, M.; Prins, J.M. Knowledge and use of antibiotics in six ethnic groups: The HELIUS study. Antimicrob. Resist. Infect. Control 2019, 8, 200. [CrossRef]

62. Bradley, S.F. Principles of antimicrobial therapy in older adults. Clin. Geriatr. Med. 2016, 32, $443-457$. [CrossRef]

63. Rockenschaub, P.; Hayward, A.; Shallcross, L. Antibiotic prescribing before and after the diagnosis of comorbidity: A cohort study using primary care electronic health records. Clin. Infect. Dis. 2019, ciz1016. [CrossRef] 
64. Baskaran, V.; Murray, R.L.; Hunter, A.; Lim, W.S.; McKeever, T.M. Effect of tobacco smoking on the risk of developing community acquired pneumonia: A systematic review and meta-analysis. PLoS ONE 2019, 14, e0220204. [CrossRef]

65. Huang, C.; Shi, G. Smoking and microbiome in oral, airway, gut and some systemic diseases. J. Transl. Med. 2019, 17, 225. [CrossRef]

66. GBD 2016 Alcohol and Drug Use Collaborators. The global burden of disease attributable to alcohol and drug use in 195 countries and territories, 1990-2016: A systematic analysis for the Global Burden of Disease Study 2016. Lancet Psychiatry 2018, 5, 987-1012. [CrossRef]

67. Rehm, J.; Gmel, G.E.S.; Gmel, G.; Hasan, O.S.M.; Imtiaz, S.; Popova, S.; Probst, C.; Roerecke, M.; Room, R.; Samokhvalov, A.V.; et al. The relationship between different dimensions of alcohol use and the burden of disease-An update. Addiction 2017, 112, 968-1001. [CrossRef] [PubMed]

68. Md Rezal, R.S.; Hassali, M.A.; Alrasheedy, A.A.; Saleem, F.; Md Yusof, F.A.; Godman, B. Physicians' knowledge, perceptions and behaviour towards antibiotic prescribing: A systematic review of the literature. Expert. Rev. Anti-Infect. Ther. 2015, 13, 665-680. [CrossRef] [PubMed]

69. Gianino, M.M.; Lenzi, J.; Bonaudo, M.; Fantini, M.P.; Ricciardi, W.; Damiani, G. Predictors and trajectories of antibiotic consumption in 22 EU countries: Findings from a time series analysis (2000-2014). PLoS ONE 2018, 13, e0199436. [CrossRef] [PubMed]

70. Min, L.; Galecki, A.; Mody, L. Functional disability and nursing resource use are predictive of antimicrobial resistance in nursing homes. J. Am. Geriatr. Soc. 2015, 63, 659-666. [CrossRef]

(C) 2020 by the authors. Licensee MDPI, Basel, Switzerland. This article is an open access article distributed under the terms and conditions of the Creative Commons Attribution (CC BY) license (http://creativecommons.org/licenses/by/4.0/). 